\title{
The Compassion of Zarathustra: Nietzsche on Sympathy and Strength
}

\section{Citation}

Frazer, Michael. 2006. The compassion of Zarathustra: Nietzsche on sympathy and strength. Review of Politics 68, no. 1: 49-78.

\section{Published Version}

http://dx.doi.org/10.1017/S0034670506000052

\section{Permanent link}

http://nrs.harvard.edu/urn-3:HUL.InstRepos:3350069

\section{Terms of Use}

This article was downloaded from Harvard University's DASH repository, and is made available under the terms and conditions applicable to Other Posted Material, as set forth at http:// nrs.harvard.edu/urn-3:HUL.InstRepos:dash.current.terms-of-use\#LAA

\section{Share Your Story}

The Harvard community has made this article openly available.

Please share how this access benefits you. Submit a story.

\section{Accessibility}


The final, definitive version of this article was published in The Review of Politics 68:1 (February 2006), pp. 49-78 by Cambridge University Press. All rights reserved. (C) 2006 University of Notre Dame. Available online at http://journals.cambridge.org.

\section{The Compassion of Zarathustra: Nietzsche on Sympathy and Strength Michael L. Frazer}

Contemporary moral and political discourse, across the ideological spectrum, regularly celebrates sentiments of sympathy or compassion. ${ }^{1}$ Most canonical philosophers would take issue with this current vogue for shared suffering; Friedrich Nietzsche is far from unique in this regard. Indeed, Nietzsche acknowledges that the "overestimation of and predilection for compassion [des Mitleidens] on the part of modern philosophers is something new: hitherto philosophers have been at one as to the worthlessness of compassion. I name only Plato, Spinoza, La Rochefocauld and Kant..." (GM Preface 5, p. 455). ${ }^{2}$ With many such philosophers, however, compassion is ignored, downplayed, or written-off more than it is actively opposed, often lumped together with all other strong emotions as an irrational "passion" to be subdued by "reason."

Yet Nietzsche was hardly an opponent of the non-rational passions as such, ${ }^{3}$ and his critique of compassion is singular in both its extent and its vehemence. Indeed, the revaluation of compassion is one of the central themes, if not the central theme, in Nietzsche's immoralist ethics. In addressing the value of morality, Nietzsche explains, he "had to come to terms almost exclusively" with his "great teacher Schopenhauer" (GM Preface 5, p. 455), and Schopenhauer's ethics are perhaps the most thorough philosophical defense of a pure Mitleids-Moral—an altruistic moral system motivated entirely by compassion. Nietzsche's critique of compassion, moreover, is central not only to his almost oedipal struggle with his "great teacher," but also to his futile struggle to purge the sympathetic sentiments from his own tormented soul. ${ }^{4}$ For contemporary political theorists looking for grounds for rejecting the current celebration of 
compassion in American politics and culture, Nietzsche's philosophy might therefore seem a very promising place to turn. ${ }^{5}$

Nietzsche's critique of compassion, however, cannot be of any help to us today until interpreters of Nietzsche make clear what exactly this critique involves. As recently as 1990, Henry Staten observed that while "the question of pity is never long out of sight in Nietzsche's texts... this question plays no significant role in any of the commentaries on Nietzsche that I know. ${ }^{\prime 6}$ In the decade and a half since Staten wrote, this gap in Nietzsche scholarship has begun to be filled, and Nietzsche's views on compassion are now analyzed at least in passing in many discussions of the author's thought. ${ }^{7}$ For most current commentators, the challenge is one of puzzling out the source of Nietzsche's opposition to a sentiment so many of us regard favorably; their many and varied answers to this interpretive riddle will be cited throughout this essay as the occasion warrants. Given their focus on the question of why Nietzsche is so opposed to compassion, however, most commentators today fail to question whether Nietzsche's position on the sentiment is best understood as one of straightforward "opposition" at all. ${ }^{8}$ It is the purpose of this essay to challenge the received wisdom on this topic, and suggest that Nietzsche's critique of compassion should not be understood as merely critical. To the contrary, the active endorsement of one's own compassionate feelings is characteristic of the highest specimens of humanity which Nietzsche's philosophy celebrates.

This is not to suggest that Nietzsche provides his interpreters with a systematic table of virtues and vices according to which compassion could fall neatly into the column of virtue, any more than it could neatly fit into the column of vice. "I mistrust all systematizers and I avoid them," Nietzsche writes. "The will to system is a lack of integrity" (GD "Maxims and Arrows" 26, p. 470). In order to make sense of Nietzsche's position on compassion, however, some sense 
must be made of Nietzschean ethics as a whole, and hence of the foundation on which Nietzsche builds his specific normative conclusions regarding compassion. The first section of this essay will therefore briefly stake out what I hope is a plausible position between those who deny that Nietzsche was engaged in anything resembling traditional ethical philosophy and those who see Nietzsche as nothing more than a rather heterodox Platonist or Aristotelian.

To be sure, my position in this first section must remain provisional, but my task is only to set the stage for an engagement with Nietzsche's alleged condemnation of compassion, which will take up the second, longer part of the essay. This latter section will show that an endorsement of one's compassion is actually a natural outgrowth of Nietzsche's immoralist ethics - that the noblest disciples of Zarathustra must actively embrace the sympathetic sentiments inevitably present in their own psyches. This interpretive claim should give pause to contemporary theorists who might seek to enlist Nietzsche as an obvious, unproblematic ally in their battle against the ubiquitous rhetoric of compassion today.

\section{On Nietzschean Ethics}

\section{Ethics, Not Genealogy}

One currently widespread stream of interpretation, begun by Gilles Deleuze and popularized by Michel Foucault, insists that Nietzsche had no interest in traditional ethics, but was instead primarily engaged in a groundbreaking new form of social inquiry by the name of "genealogy." This understanding of "genealogy" as the keystone of Nietzsche's philosophy, however, has not withstood critical scrutiny. ${ }^{10}$ This is not to say that Nietzsche is uninterested in the historical origins of our moral evaluations. Yet addressing these origins is a mere preliminary to answering the question that really interests Nietzsche, the question of "what value do they 
themselves [these judgments] possess?" (GM Preface 3, p. 453). "Genealogy" alone is hardly sufficient for addressing this all-important question; Nietzsche insists that "the inquiry into the origins of our evaluations and tables of the good is in absolutely no way identical with a critique of them, as is so often believed" (WM 254, p. 148). ${ }^{12}$ If he is to move from facts to values, to make claims of a normative rather than a merely historical sort, Nietzsche needs an independent foundation for such claims.

Something resembling the traditional ethical appeal to an objective teleology embedded in human nature is the most likely candidate for such a foundation. Yet it is precisely such an objective ethics which those who describe Nietzsche as a "genealogist" insist that the author cannot provide. This impossibility is often attributed to Nietszche's "perspectivism"- the doctrine that an objective ethics, like any objective knowledge, is unattainable because "there is only a perspective seeing, only a perspective 'knowing"' (GM III:12, p. 555). ${ }^{13}$ Yet perspectivism obviously does not rule out all critique or revaluation of our moral evaluations. Alexander Nehamas, for one, argues that the great crime of slave morality, the fundamental reason for its low valuation by Nietzsche, is a crime against perspectivism itself. The Christian morality of the weak, he claims, seeks "to conceal and to deny its own interpretive status" by maintaining that it is true and authoritative for all, weak and strong alike, rather than a perspectival expression of the needs of the weak alone. ${ }^{14}$

Admittedly, the rejection of perspectivism is one of the many crimes that slave morality commits, and for which Nietzsche berates it. But this is certainly not Nietzsche's greatest objection to slave morality. To the contrary, his greatest objection to slave morality is precisely that it is the morality of slaves — of the weak and the sick. Its universalism and absolutism, in turn, are objectionable, not because of their philosophical objectivism as such, but because they 
are tools by which the weak succeeded in poisoning the strong and healthy, robbing them of their natural strength and health. Luckily, however, this is "merely one type of human morality beside which other types, above all higher moralities, are, or ought to be, possible" (JGB V:202, p. $305)$.

Nietzsche's demand for a new, higher morality can be harmonized with his perspectivism when one acknowledges, following Nehamas, that Nietzsche's perspectivism need not imply ethical relativism. ${ }^{15}$ Specifically, perspectivism is entirely compatible with the idea that certain perspectives are better than others. Nietzsche captures this idea by rejecting interpretations of the world that represent "only provisional perspectives, perspectives... from some nook, perhaps from below, frog perspectives, as it were" (JGB I:2, p. 200). Nietzsche can even take this one step farther and consider that there might be one privileged perspective which is better, not just than some others, but better than all others — not in the sense of being more objective or giving a truer picture of things, but in the sense of being more urgent or more commanding. Such a perspective would be the single best perspective for human beings to take on the world; its view on existence would be ethically authoritative for creatures such as ourselves.

\section{Ethics from the Perspective of Life}

The discovery of such an ethically authoritative perspective is the hallmark of Nietzsche's mature philosophy; he refers to it repeatedly as "the perspective of life." While Nietzsche undoubtedly holds that there is "no limit to the ways in which the world can be interpreted," he also maintains that, when seen from the all-important perspective of life, every interpretation can itself be interpreted as "a symptom of growth or decline" (WM 600, p. 326). The question which dominates every aspect of Nietzsche's writings on virtually all human 
matters is thus to what extent the phenomenon in question "is life-promoting, life-preserving, species-preserving, perhaps even species-cultivating" (JGB I:4, p. 201). It is from the perspective of life that Nietzsche weighs the uses and disadvantages of history in the untimely meditation of that title, for the sake of life that he revaluates the value of truth itself at the beginning of Beyond Good and Evil, and it is from this same perspective that Nietzsche determines the worth of competing moral systems in On the Genealogy of Morals and elsewhere.

"For what reason does Nietzsche privilege this specific perspective," Henry Staten asks, "and to privilege it so massively as an interpretation of the entire history of his culture? Is it because he thinks it's true? Not if he's really a perspectivist. What then?"16 At times, strength and health in life are presented as goals to which every animal, humanity included, strives instinctively (e.g., GM III:7, p. 543). The valuations which result are "more clearly" understood as "physiological demands for the preservation of the preservation of a certain type of life" (JGB 1:3, p. 201). Yet Nietzsche does not hold that the perspective of life is the one which, as a matter of fact, we all happen to take; to the contrary, many professional valuators (prophets, priests, philosophers, etc.) have assumed an opposite perspective. Nietzsche must therefore argue that there is something wrong with those who refuse to evaluate values in terms of their uses and disadvantages for life. How can we make sense of this "wrongness," and of the apparently unconditional "ought" which it implies, in a manner consistent with Nietzsche's work as a whole?

The answer to our question lies in the possibility, famously suggested by Martin Heidegger, that Nietzsche may not actually be "nearly so subversive as he himself was wont to pose." ${ }^{17}$ Heidegger, for one, argues that Nietzsche succeeds only in "inverting" Platonic metaphysics, never truly "overcoming" it. ${ }^{18}$ Peter Berkowitz makes an argument analogous to 
Heidegger's concerning Nietzsche's ethics specifically; Nietzsche here emerges as more of an inverted Aristotle than an inverted Plato, analyzing human life in terms of natural potentialities that establish natural virtues or excellences necessary for the good life. ${ }^{19}$ Berkowitz thus adamantly rejects Nehamas's contention that Nietzsche's perspectivism prohibits grading "people and views along a single scale,, 20 there is, from the perspective of life, precisely such a single scale of excellence - an order of rank in terms of natural, vital virtue (arete in the Aristotelian sense) - the excellence of the natural aristocracy as established by the teleology of human life. For this reason, John Rawls classifies Nietzsche alongside Aristotle as a "perfectionist." 21

Nietzsche's conception of human perfection, of course, is rather different from Aristotle's ideal of virtuous moderation. The excellent man under Nietzsche's ethics seeks "not virtue but fitness (Renaissance virtue, virtù, virtue that is moraline-free)." (AC 2, p. 570). In rejecting the content of Aristotelian ethics, however, Nietzsche insists that he has not rejected its categories, most notably that of virtue itself. ${ }^{22}$ To the contrary, he has done them a great service; "I have imparted to virtue a new charm—-the charm of something forbidden," Nietzsche proudly notes. "It appears as a vice" (WM 328, p. 179). Now in keeping with our vital instincts, this new and improved version of virtue has a natural appeal. "One would make a little boy stare if one asked him: 'Would you like to become virtuous?'” goes one charming account of this appeal, "but he will open his eyes wide if asked: 'Would you like to become stronger than your friends?"' (WM 918, p. 485).

\section{Value Creation and the Limits of Nietzchean Ethics}


The interpretation of Nietzsche outlined in the previous section notwithstanding, it is impossible to deny that there are many strikingly relativist passages in Nietzsche's ethical writings which, even as they make use of the traditional concept of virtue, might be taken to prohibit us from considering any specific virtue the product of natural, Aristotelian teleology. ${ }^{23}$ "A thousand goals have there been so far," Zarathustra says, "for there have been a thousand peoples." Yet, unlike today's cultural relativists, Zarathustra does not stop here. "The one goal is still lacking," he says. "Humanity still has no goal. But tell me, my brothers, if humanity still lacks a goal—is humanity itself not still lacking too?" (Z I "On the Thousand and One Goals," p. 172) If all goods and goals are individually or culturally relative, however, what could ever be the one telos for all of humanity?

Nothing other, Nietzsche would answer, than the telos of setting tele—of positing goals, of esteeming and condemning, in short, of creating values. "No people could live without first esteeming," he writes (Z I "On the Thousand and One Goals," p. 170). In this way, "life itself forces us to posit values; life itself values through us when we posit values" (GD "Morality as Anti-Nature" 5, p. 490). Indeed, such valuing is, for Nietzsche, the very essence of life. "Is not living—estimating, preferring, being unjust, being limited, wanting to be different?” (JGB I:9, p. 205). Thus, from the authoritative perspective of life, "esteeming itself is of all esteemed things the most estimable treasure." (Z I "On the Thousand and One Goals," p. 171). Nietzsche explains that life, as the will to power, is healthy insofar as it can successfully reach out and incorporate others into one's own projects. Yet violent coercion of an inferior can hardly achieve this goal; "while a crude injury done him certainly demonstrates our power over him, it at the same time estranges his will from us even more—and thus makes him less easy to subjugate" (WM 769, pp. 403-404). Only by legislating values, values which are then fully internalized by the wills of 
others, can one get around the futility of wielding more widely-recognized forms of great power. Thus, Nietzsche writes, "he who determines values and directs the will of millennia by giving direction to the highest natures is the highest man" (WM 999, p. 519).

The telos of value-creation is the crux of Nietzsche's ethical theory. Any formally Aristotelian moral philosophy gains substance and content only through the essential potentialities it places at the center of human nature. According to Nietzsche, man is not (as Aristotle would have it) the essentially rational, or the essentially political, animal but instead “the calculating [or 'valuating,' as Kaufmann translates it] animal” (GM II:8, p. 506). Or, as Nietzsche puts it in Beyond Good and Evil, man is the "as yet undetermined animal," the creature that must make its way in the world by choosing its own goals, and hence its own values (JGB III:62, p. 264). The unique form of this telos allows Nietzsche to come close to overcoming, rather than merely overturning, Aristotelian ethics. If the nature of man is to have an undetermined nature, if the natural end of human life is the selection of one's own ends, then it is impossible to produce a single, universally valid table of virtues and vices of the sort familiar from the middle books of the Nicomachean Ethics. To borrow a phrase from Staten, the telos of value-creation as the ultimate sign of health is a "telos which is the undoing of all teleology."24 The unthinking celebration of health and strength, of master morality, or even of value creation itself, is thus an evasion of man's highest responsibility and hence a sign of weakness. This is why Nietzsche writes that the strongest today are not found simply adhering to the oldfashioned morality of good and bad, as opposed to the now-common morality of good and evil. Instead, "today there is perhaps no more decisive mark of a "higher nature... than that of being... a genuine battleground of these opposed values" (GM I:16, p. 488). Nietzsche ultimately cannot tell those of us strong enough to choose our own values to choose one particular moral 
code. All he can do is describe the sort of choices characteristic of such noble individualschoices that shine forth as signs of their natural strength. Most obviously, the strong who have not been poisoned by slave morality or who have overcome this poisoning will normally tend to value themselves; value creation is at its most basic an act of self-affirmation. The naturally noble call the traits of character bound up with their psychic strength by the names of the virtues. ${ }^{25}$ For a physician of the soul such as Nietzsche, these traits are best understood as diagnostic signs of psychic health; the positive self-evaluation of the strong themselves turns these positive symptoms into moral virtues.

The choices of the truly noble must remain fully their own and cannot be entirely predicted prior to any given act of value creation. This puts severe limitations on the ethicist's work as a physician of the soul. Nietzsche writes:

The popular medical formulation of morality that goes back to Ariston of Chios, "virtue is the health of the soul," would have to be changed to become useful, at least to read "your virtue is the health of your soul." For there is no health as such... Even the determination of what is healthy for your body depends on your goal, your horizon, your energies, your impulses... In one person, of course, this health could look like its opposite in another person (FW 3:120, pp. 176-177). ${ }^{26}$

The result of Nietzsche's understanding of psychic health is that "the very same symptoms could point to decline and to strength" (WM 110, p. 69). Nietzschean ethics thus emerges as a particularly difficult form of intellectual inquiry; the signs of natural health and strength which mark the value-creating choices of the natural aristocracy must be carefully sifted from the signs of decadence and decline which mark the almost identical pseudo-choices of the weak and ill. This leads to a strange doubling throughout Nietzsche's ethics, as the same 
phenomena appear at one moment as signs of health, and, in an ever-so-subtly different form, as symptoms of weakness. There is a philosophical asceticism of which Nietzsche approves and a priestly one of which he does not; a skepticism which he condemns and another which he endorses; and, perhaps most famously, a pessimism of weakness and a pessimism of strength. ${ }^{27}$ We should not, then, expect a simple or straightforward categorization of the sympathetic sentiments. To the contrary, we should expect to find closely related emotions in both categories: a compassion of weakness endorsed by slave morality and a compassion of strength embraced by the natural aristocracy. ${ }^{28}$

\section{The Case of Compassion}

\section{More Dangerous Than Any Vice}

In discussing what can be translated into English alternately as "pity," "sympathy" or "compassion," Nietzsche almost always uses variations on the German term Mitleid-literally, "suffering-with" - and only rarely uses alternative German terms such as Mitempfinden, Mitgefühl (both "feeling-with") or Sympathie. Nietzsche was never entirely satisfied with the vocabulary available in German to describe the phenomenon in question—he complains "how coarsely does language assault with its one word [i.e., Mitleid] so polyphonous a being!"”-but it is the vocabulary he uses nonetheless (MR 2:133, p. 133). The English word "compassion," from the Latin for "suffering with" (com-passion), or "sympathy" from the Greek for the same (sympathos), would be appropriate translations of Mitleid. In virtually all English-language translations of and commentaries on Nietzsche, however, variations on the term "pity" are chosen instead. ${ }^{29}$ Yet "pity," which has an entirely different etymology, often carries negative connotations of superficiality and condescension which Mitleid lacks. ${ }^{30}$ Perhaps much of the 
subtlety of Nietzsche's position on Mitleid has been overlooked in the English-speaking world at least in part because of the widespread translation of the term as "pity." 31

Regardless of how Mitleid is translated, however, Nietzsche's condemnation of the sentiment could hardly appear more straightforward to a superficial reader. As has been established, Nietzsche evaluates any human phenomenon as a symptom of strength or weakness, a sign of the advancement of life or of its decline. His question concerning compassion is thus, "Is it, above all else, good for you yourselves to be compassionate [mitleidige] men?" (FW IV:338, p. 269). The answer seems obvious. "Compassion [Mitleiden],” Nietzsche writes, "insofar as it really causes suffering [Leiden] —and this is here our only point of view—is a weakness" (MR II:134, p. 134). “One is deprived of strength when one feels compassion [mitleidet]," he explains. "Compassion makes suffering contagious," and therefore "stands opposed to the tonic emotions which heighten our vitality" (AC 7, pp. 572-573). ${ }^{32}$ Yet this line of argument, taken in isolation, would categorize compassion one weakness among many others, little different from the suffering which it leads one to share, and Nietzsche's critique of the sentiment seems to go much further. ${ }^{33}$ "The virtue of which Schopenhauer still taught that it is the supreme, the only virtue, and the basis of all virtues," Nietzsche wrote in his notes, "precisely compassion [Mitleiden] I recognized as more dangerous than any vice" (WM 54, p. 34). How is this unique status of compassion to be understood?

Perhaps we should turn our attention from the subject of compassion to its object.

Nietzsche does ask whether such an emotion is good, not only for those who feel it, but also "for those who suffer [den Leidenen]" (FW IV:338, p. 269). His answer here, too, is that compassion is of no value; "if one does good merely out of compassion [Mitleid], it is oneself one really does good to, and not the other" (WM 368, p. 199). To be sure, one's painful sympathy may be 
soothed, but the object of this sympathy has been shamed by the condescension charity implies, and, even more importantly, been deprived of the opportunity to build real strength from his own efforts to overcome his suffering. Indeed, the potential value of suffering as a challenge to be met head-on, a spur to greatness, and a test of one's mettle is a central theme in Nietzsche's ethics. "It almost determines the order of rank," he repeatedly insists, "how profoundly human beings can suffer" (JGB IX:270. p. 410). "To those of my disciples who have any concern for me," Nietzsche therefore reasons, "I wish suffering, desolation, sickness, ill-treatment, indignities... I have no compassion [Mitleid] for them, because I wish them the only thing that can prove today whether one is worth anything or not" (WM 910, p. 481). ${ }^{34}$

These are all strong arguments against compassion, to be sure. But Nietzsche insists that there is still "a more important one... Quite in general, compassion [das Mitleiden] crosses the law of development, which is the law of selection. It preserves what is ripe for destruction, it defends those who have been disinherited and condemned by life" (AC 7, p. 573). ${ }^{35}$ The eugenic argument against compassion is a direct extension of the medical nature of Nietzschean ethics. 'Life itself recognizes no solidarity, no 'equal rights,' between the healthy and the degenerate parts of an organism: one must excise the latter — or the whole will perish," Nietzsche explains. As a result, "Compassion for [Mitleiden mit] decadents, equal rights for the ill-constituted-that would be the profoundest immorality; that would be antinature itself as morality!” (WM 734, p. 389). The physician to humanity, in order to save it from its degenerate parts, must therefore first play physician to the individual psyche, for it is the compassion in the individual that feeds the degeneracy in the collective. "To be physicians here, to wield the scalpel here," Nietzsche explains, "that is our part; that is our love of man; that is how we are philosophers" (AC 7, p. $574)$. 
Even this eugenic view, however, fails to capture the full danger of compassion, for it portrays the weak and sickly who are its objects as mere passive recipients of aid. To the contrary, compassion is actively wielded as a weapon in the hands of the weak. For the most degenerate of the degenerate, it is the one weapon they have left, the one last strength which shows that they are still alive as manifestations of the will to power. They therefore wield compassion with relish. When the weak beg the strong for sympathy, "the compassion [Das Mitleiden] which these [the strong] then express is a consolation for the weak and suffering, inasmuch as it shows them that, all their weakness notwithstanding, they possess at any rate one power: the power to hurt" (MAM I:50, p. 39). The result is not only the objective degeneration of humanity over the generations, but also a subjective sense of shame on the part of those who remain strong. Full power over another, remember, is control over his values. The ultimate victory of the slaves over the masters thus comes when they have "succeeded in poisoning the consciences of the fortunate with their own misery, with all misery, so that one day the fortunate begin to be ashamed of their good fortune and perhaps say to one another: 'it is disgraceful to be fortunate: there is too much misery"' (GM III:14, p. 560).

According to Nietzsche, the recent development of Schopenhauer's Mitleids-Moral is evidence that slave morality is finally coming to self-consciousness, stripping itself of its theological underpinnings and realizing that it is founded on nothing more (or, for that matter, nothing less) than the coercive power of compassion, the one great weapon of the weak. Mitleids-Moral hence has the advantage of a certain clear-headedness, a certain lack of illusions about itself not present in earlier (e.g., Christian) forms of slave morality. But it is slave morality all the same and, from the perspective of life, deserves the fiercest ethical opposition. 


\section{Compassion versus Compassion}

Nietzsche is undoubtedly filled with rage at those who bring about the degeneration of humanity by obtaining the compassion of their natural superiors, rage seemingly justified from the perspective of life. Nonetheless, his precise feelings toward compassion take a rather surprising form. "Anyone... who approached this almost deliberate degeneration and atrophy of man represented by the Christian European... would surely have to cry out in wrath, in compassion [mit Mitleid], in horror: 'O you dolts, you presumptuous, compassionate [mitleidigen] dolts, what have you done!" (JGB III: 62, p. 265). Nietzsche, in other words, reacts to the sight of humanity diminishing itself through compassion with compassion, albeit a "higher and more farsighted compassion [Mitleiden]" than the Christian and quasi-post-Christian moralists' foolish hatred of sheer suffering. "Thus," Nietzsche concludes, "it is compassion versus compassion [Mitleid also gegen Mitleid]" (JGB VII:225, pp. 343-344). Given all of Nietzsche's arguments outlined above, however, how can he possibly endorse compassion in any form? Can there really be a compassion of strength?

One might answer in the negative, while finding some appropriately noble disposition that could perform an analogous function in the case of the strong and pitiless. Such a sentiment would lead the naturally healthy aristocrat to the service of a degenerating humanity without dragging him into the great cesspool of human suffering. To the contrary, it would grow naturally from the very health and power which keeps the nobleman at such a distance from his miserable inferiors. If Nietzsche, at times, still speaks of this sentiment as a sort of compassion, he is using the word very loosely, and primarily for ironic effect. And the best candidate for such a noble replacement for compassion is the "gift-giving virtue" discussed throughout Thus Spoke Zarathustra. In the prologue of that epic work, our hero at first tells the saint that he has left his 
lofty seclusion out of a (compassionate?) love of lesser men. Quickly, however, Zarathustra corrects himself. "Did I speak of love? I bring men a gift" (Z Prologue:2, p. 123). Nor is the giftgiving virtue a mere quirk of Nietzsche's protagonist; on the contrary, it is integral to the author's conception of health and strength. "Those poor in life, the weak, impoverish life," he writes. "Those rich in life, the strong, enrich it. The first are parasites of life; the second give presents to it" (WM 48, p. 30). If you are naturally, vitally noble you will inevitably "force all things to and into yourself that they may flow back out of your well as the gifts of your love" ( $Z$ I "On the Gift-Giving Virtue," 1 p. 187).

The gift-giving virtue, however, is by no means a form of compassion, let alone a compassion of strength. Instead, it is compassion's usurper and replacement. "The noble human being... helps the unfortunate, but not, or almost not, from compassion [nicht oder fast nicht aus Mitleid], but prompted more by an urge begotten by excess of power" (JGB IX:260, p. 395). Yet one should not overlook or underestimate that "fast." $"$ "To suggest that Nietzsche is discussing the gift-giving virtue when he approves of compassion does violence to his insistence that his "higher" Mitleid still deserves that otherwise lowly appellation. A genuinely compassionate form of compassion is, for Nietzsche, still actively present in the noble soul.

\section{A Weakness of the Strong?}

Our interpretive puzzle becomes especially salient when one focuses on Nietzsche's pseudo-scriptural epic Thus Spoke Zarathustra. Generally speaking, the eponymous hero of that work is a paragon of strength and health. Yet Zarathustra shamefacedly admits quite early on that he is unable to live up to his own vital ethics in one crucial regard. "If I must be compassionate [mitleidig]," Zarathustra says, "at least I do not want it known; and if I am compassionate, it is 
preferably from a distance... Therefore I wash my hand when it helped the sufferer; therefore I wipe even my soul.” (Z II: “On the Compassionate,” pp. 200-201). Zarathustra's struggle with unwanted compassion takes center stage in Part IV, and the work climaxes with the prophet's ultimate triumph. Yet the author feels no need to burden his protagonist with other weaknesses or infirmities. Why would Zarathustra be plagued by compassion exclusively?

Compassion may be a weakness, but it is a distinctive sentiment of the otherwise relatively strong. To be subject to infection by another's suffering one's own condition must initially be superior to his, so a feeling of compassion signals that one ranks higher than this suffering other. Although the degenerating effect of sympathetic suffering may soon drag one down to the sufferer's lowly condition, we must not discount the vitalizing effect of the initial realization of one's superiority. And it is precisely because those at risk of experiencing compassion are relatively strong that this emotion is such a powerful weapon in the hands of their inferiors. The "Jesuitism of mediocrity, which instinctively works at the annihilation of the uncommon man and tries to break every bent bow, or, preferably, to unbend it" is armed exclusively with this sentiment. "Unbending with familiar compassion, that is the characteristic art of Jesuitism which has always known how to introduce itself as a religion of compassion [des Mitleidens]" (JGB VI: 206, p. 316). Compassion is thus the weapon such Jesuits use in their attempt to destroy Zarathustra, whose Achilles' heel is his soft heart.

Nietzsche realizes these implications of his analysis, but is also quick to deflate them. The experience of compassion demonstrates only that sympathizers rank a single step higher than the objects of their sentiments. Compassionate individuals' absolute standing may nonetheless remain quite low, as it must be if they exult in the sudden realization of their superiority to mere sufferers. "Compassion [Mitleid] is the most agreeable feeling among those 
who have little pride and no prospects of great conquests," Nietzsche writes; "for them easy prey — and that is what all who suffer [jeder Leidende] are—is enchanting. Compassion is praised as the virtue of prostitutes" (FW I:13, p. 88). For those of middling rank, compassion can thus be a means of turning one's attention from the debilitating sight of one's superiors to the more pleasing sight of one's inferiors. "As long as Prometheus feels compassion [Mitleid] for men and sacrifices himself for them, he is happy and great," runs Nietzsche's parable on this subject; "but when he becomes envious of Zeus and the homage paid to him by mortals, then he suffers" (FW III:251, p. 216). Surely, however, compassion is not to be found in, let alone found pleasant by, he who stands at the very top of the order of rank.

Zarathustra, however, has heard otherwise. "Thus spoke the devil to me once," he recounts. “'God too has his hell: that is his love of man.' And most recently I heard him say this: 'God is dead; God has been killed by his compassion [Mitleiden] for man"” (Z II "On the Compassionate," pp. 202). This possibility intrigues Zarathustra immensely, and the last, retired pope later confirms the tale (Z IV "Retired," pp. 372-373). A compassion of the strong, however, is very far from a compassion of strength if it ultimately debilitates and kills formerly great gods. A true compassion of strength would not be the distinctive symptom of the imminent demise of the once strong, but an expression of life and power successfully at work in the very moment of compassion.

\section{Knowledge, Suffering and Strength of Imagination}

That a true compassion of strength may indeed exist is suggested by the vital category of the Dionysian — a category that, though its contents are fluid and often obscure, Nietzsche clearly endorses wholeheartedly. In his earliest work, still largely under the spell of Schopenhauer, 
Nietzsche describes the Dionysian as involving a break through the principium individuationis, culminating in ecstatic unity and the sharing of all emotions, suffering included (See GT 2, p. 40). Although one might argue that the significance of the Dionysian changes over the course of Nietzsche's career, the element of universal unity and compassion remains constant throughout. In a note from June 1888, mere months before his final breakdown, Nietzsche writes that "the word 'Dionysian' means: an urge to unity, a reaching out beyond personality... the great pantheistic sharing of joy and suffering [Mitfreudigkeit und Mitledigkeit]" (WM 1050, p. 539). ${ }^{37}$

There is, Nietzsche recognizes, a specific sort of strength at work when one breaks through the principium individuations to share in another's suffering. Specifically, the strength of one's imagination allows for a bridging of the divide between individuals and the picturing of another's suffering from his own perspective. Without such imaginative strength, compassion is impossible. "The great lack of imagination [Phantasie] from which [the mediocre man] suffers means that he is unable to feel his way into [hineinfühlen, i.e., empathize with] other beings," Nietzsche observes, "and thus he participates as little as possible in their fortunes and sufferings [Leiden]" (MAM I:33, p. 29). The compassionate man has an imaginative intelligence, and hence a kind of knowledge, which the unimaginative, ignorant man lacks. "That the other suffers [leidet] has to be learned," Nietzsche insists, and this is a lesson that seems inseparable from compassion.

Or is compassion perhaps separable from this lesson, perhaps even opposed to it? "In a man devoted to knowledge," Nietzsche writes, "compassion [Mitleiden] seems almost ridiculous, like delicate hands on a Cyclops" (JGB IV:171, p. 262). Nietzsche even suggests that compassion, at least as it is usually experienced, acts against knowledge of suffering by providing a false, overly generalized picture of another's woe. "It is the very essence of the 
emotion of compassion [der mitleidigen Affection] that it strips away from the suffering of others whatever is distinctively personal," he explains. "When people try to benefit someone in distress, the intellectual frivolity with which those moved by compassion [der Mitleidige] assume the role of fate is for the most part outrageous; one simply knows nothing of the whole inner sequence and intricacies that are distress for me or for you" (FW IV:338, p. 269). ${ }^{38}$

In contrast to this compassion which "gets things wrong," Nietzsche paints a rather mysterious alternative which somehow "gets things right." This is a "more manly brother of compassion [männlicheren Bruder des Mitleidens]" (MR I:78, p. 79) Nietzsche writes; it is "a feeling for which I find no name accurate" (WM 367 pp. 198-199). At one point, this unnamable Übermitleid is identified with the "species of suffering" experienced only when "the genius of ability and of knowledge is amalgamated with moral genius in the same individual." Such a man has "an extra- and supra-personal sensibility attuned to a nation, to mankind, to a whole culture, to all suffering existence [allem leidenden Dasein], which acquires its value through its connection with very difficult and remote forms of knowledge." In contrast to such a sensibility, "compassion itself [Mitleid an sich] remains of very little value" (MAM I:157, p. 84).

At another point, Nietzsche insists the sensibility he is advocating is actually not a sort of suffering, not a sort of Leid or Mitleid, at all. It is not compassion, he writes, "that opens the gates to the most distant and strange types of being and culture" but rather a kind of empathy that “does not 'suffer with' [nicht 'mitleidet'] but on the contrary takes delight in a hundred things that... led people to suffer." This manlier brother of compassion is a sort of "feeling-with and knowing-with [Mitempfindung und... Mitwissen]" which is nonetheless "far from being... compassionate [mitleidig]" (MR II:113, p. 113). In today's English terminology, it is a joyous, sometimes cruel empathy that pitilessly penetrates into another's experience of suffering without 
ever coming to feel this suffering itself. This empathy may emotionally overwhelm those who experience it, but Nietzsche insists that their delightful pain is not compassionate. "[E]ven when we are shaken by the sight of suffering and moved to tears," he writes, "we do not by any means for that reason feel like helping" (WM 119, pp. 72-73).

It is a strange form of delight, however, which shakes one by the sight of suffering and brings one to tears. Such tears look suspiciously like the sharing of suffering, a sharing essential to real knowledge of another's woe. Admittedly, philosophers today still speak of an empathetic sadism that delights in the suffering of another, not because it lacks full knowledge or experience of this suffering, or even despite such knowledge, but precisely through its sweet savor. Indeed, the initial observation of such cruel empathy is even credited to Nietzsche himself. ${ }^{39}$ Sadistic empathy, however, seems unable to truly access the sufferings of others, entirely numb as it is to their pain's very painfulness. As Rousseau says of another's suffering, "to see it without feeling it is not to know it." ${ }^{40}$ The truth of another's pain thus seems epistemologically inaccessible without an experience that itself qualifies as suffering, and hence as Mitleid or compassion.

To be sure, compassion as we actually experience it does not itself always get things right. The pain of another can be misfelt and hence misunderstood. Yet any emotion which does successfully accesses another's suffering will surely qualify as compassion. Indeed, the more accurate a picture of another's suffering a sentiment provides, the more fully does it deserve the name of compassion. "What Nietzsche names with... other names," Staten reasons, "is therefore true Mitleid, the deep and genuine version of that which Mitleid usually names. ${ }^{.41}$ Nietzsche himself concedes as such. "Anyone who, in intercourse with men, does not occasionally glisten in all the colors of distress," he admits, "green and gray with disgust, satiety, sympathy 
[Mitgefühl], gloominess and loneliness, is certainly not a man of elevated tastes... he was not made, he was not predestined, for knowledge" (JGB II:26, p. 227). ${ }^{42}$

\section{Compassion as Test}

Although Nietzsche acknowledges that the truly knowledgeable must also be compassionate, he is also famous for arguing that the truth is often of only dubious advantage to life. It is thus not clear that the knowledge that compassion brings is worth having, at least from the perspective of life. In evaluating compassion, Nietzsche is thus faced with a paradox: Insofar as a man has great strength of imagination and intellect, he will accurately feel the sufferings of others. Yet insofar as a man feels the sufferings of others, he may turn against his life and health. Weakened by his compassion, he may even be brought down to the level of those whose sufferings he witnesses. In this way, "compassion [Mitleiden] is the deepest abyss: as deeply as man sees into life, he also sees into suffering" (Z III: "On the Vision and the Riddle," 1, pp. 269).

The paradox is especially pressing for someone who seeks knowledge of that specific form of human suffering that Nietzsche describes as the object of his greatest interest: the degeneration of humanity and of its highest specimens. "The more a psychologist—a born and inevitable psychologist and unriddler of souls - applies himself to the more exquisite cases and human beings," Nietzsche writes, "the greater becomes the danger that he might suffocate from compassion [am Mitleiden]... For the corruption, the ruination of the higher men, of the souls of a stronger type, is the rule: it is terrible to have such a rule always before one's eyes" (JGB IX:269, p. 407). It is precisely this sort of depressing, perhaps even debilitating, knowledge of 
higher men, however, that is central to Nietzsche's ethical inquiry. The final part of Nietzsche's masterpiece Thus Spoke Zarathustra consists almost entirely in case studies of these near-greats. How could one understand the higher men without sharing in their characteristic misery, experiencing compassion, and hence being suffocated by sympathetic suffering?

This problem is solved when we understand the Mitleid inevitably faced by the imaginative unriddler of human souls as a test of strength akin to the Leiden Nietzsche wishes for his disciples. Just as the ability to withstand personal suffering is crucial for establishing an individual's true rank, so too could one "determine value and rank in accordance with how much and how many things one could bear to take upon oneself, how far one could extend one's responsibility" (JGB VI:212, p. 327) with regard to the suffering of others. In this way, the lifepromoting aspect in compassion, as Nietzsche puts it with regard to his own case, "does not consist in feeling with [mitzufühlen] men how they are, but in enduring that I feel with them" (EH "Why I Am So Wise" 8, p. 689). If compassion is indeed inseparable from a certain kind of knowledge - knowledge of the truth of others' suffering — then the test of compassion is part of a larger series of trials through which the noble philosopher must pass. "How much truth does a spirit endure, how much truth does it dare? More and more that became for me the real measure of value" Nietzsche writes. "Error... is not blindness; error is cowardice" (EH Preface 3, p. 674). The challenge regarding the specific truth of others' suffering is to feel compassion for them, and to feel it with full force, but "not to remain stuck" to it (JGB II:41, p. 242). Mitgefühl is thus included alongside courage, insight and solitude as one of the four virtues which a noble man must "master"-not only in the sense of possessing these virtues, but also in the sense of putting them to the service of life's further advancement (JGB IX:284, p. 416). "This is the exception," Nietzsche explains, "where, against my wont and conviction, I side with the 
'selfless' drives: here they work in the service of self-love, of self-discipline" (EH "Why I Am So Clever 8, p. 710). It is thus not actually compassion itself, but rather "the overcoming of compassion [Überwindung des Mitleids]" which counts "among the noble virtues" (EH "Why I Am So Wise" 4, p. 684).

At one point in Beyond Good and Evil, Nietzsche presents a vivid portrait of the selfloving, self-disciplined nobleman, the man for whom (and only for whom) there can be a genuine compassion of strength:

A man who says, "I like this, I take this for my own and want to protect it and defend it against anybody;" a man who is able to manage something, to carry out a resolution, to remain faithful to a thought, to hold a woman, to punish and prostrate one who presumed too much; a man who has his wrath and his sword and to whom the weak, the suffering, the hard pressed, and the animals like to fall and belong by nature, in short a man who is by nature a master — when such a man has compassion [Mitleiden], well, this compassion has value [dies Mitledien hat Wert]" (JGB IX:293, p. 420). ${ }^{43}$

As vivid as it is, however, this is a rather odd and incomplete portrait. How exactly does such a nobleman, naturally a master of others, come to master himself and his own compassion, hence giving it value? Certainly not by purging the emotion from his psyche entirely, for then one cannot say that the natural master still "has" compassion, and that this compassion "has" value. Fortunately, Nietzsche provides another, fuller portrait of a great man wrestling with his own compassion: the title character in Thus Spoke Zarathustra, who is simultaneously the imperfect embodiment of Nietzsche's ethical ideal and the author's alter ego. Upon examination, the figure of Zarathustra implies a rather different approach to shared suffering than "the overcoming of compassion" might suggest. 


\section{Zarathustra's Ultimate Triumph}

“As 'Zarathustra's temptation,"” Nietzsche recounts, "I invented a situation in which a great cry of distress reaches him, as compassion [das Mitleiden] tries to attack him as a final sin that would entice him away from himself” (EH "Why I Am So Wise” 4, p. 684). ${ }^{44}$ This temptation takes center stage in the final quarter of the work, with a soothsayer's explicit announcement that compassion has been "saved up" for our protagonist as his last great vice (Z IV "The Cry of Distress, p. 354). "To remain the master at this point," Nietzsche explains, "to keep the eminence of one's task undefiled... that is the test, perhaps the ultimate test, which a Zarathustra must pass_-his real proof of strength" (EH "Why I Am So Wise” 4, p. 684). Nietzsche's hero is thus sent off for a trying and terrible day of encounters with the "higher men," precisely the sort of near-misses which are so likely to choke a psychologist with compassion. Compassion naturally poses the greatest test for the strong with regard to this most painful of all forms of the emotion, compassion "for higher men into whose rare torture and helplessness some accident allowed us to look" (JGB II:41, p. 242).

Though each higher man deserves full attention, representing as they do the ripest fruit of Nietzsche's studies of the almost-great, for our purposes we must focus instead on Zarathustra's reaction to them. And of all the emotions toward the higher men that Zarathustra struggles to master, perhaps most interesting are those from his encounter with the "ugliest man." Even as this grotesque figure is about to praise Zarathustra for his relative lack of compassion — a sign of natural strength so radically different from the weakness of the pitying, pitiful mob, who madly call their compassion "virtue itself”- our hero falls prey to precisely such vulgar feelings. Zarathustra experiences compassion like a blow from a great enemy, described with an 
appropriately Homeric simile. Upon seeing the ugliest man's unbearable face, “Compassion [Das Mitleiden] seized him, and he sank down all at once, like an oak tree that has long resisted many woodcutters - heavily, suddenly, terrifying even those who wanted to fell it" (Z IV "The Ugliest Man," p. 376). His interlocutor, in turn, sees that Zarathustra knows the truth of compassion's ethical danger. As the ugliest man remarks, paraphrasing our protagonist's prophecy from Part I (Z I “On the Pitying,” p. 202 ), “When you say, 'From compassion [dem Mitleiden], a great cloud approaches; beware, O men!'... O Zarathustra, how well you seem to understand storm signs." Such an abstract realization, however, is not enough; as an all-too-often object of all-too-human sympathy can recognize all too well, the prophet is not yet strong enough to internalize his own teaching. "Warn yourself also against your compassion!" the ugliest man thus implores Zarathustra (Z IV “The Ugliest Man,” p. 378).

It is only the following morning, as the book comes to its dramatic close, that Zarathustra achieves victory in his great test. The moment of this triumph, certainly one of the literary highpoints of Nietzsche's oeuvre, is worth quoting in its entirety:

"O you higher men, it was your distress that this old soothsayer prophesied to me yesterday morning. To your distress he wanted to seduce and tempt me. 'O Zarathustra,' he said to me, 'I come to seduce you to your final sin.' To my final sin?' shouted Zarathustra, and he laughed angrily at his own words; "what was it that was saved up for my final sin?" And once more Zarathustra became absorbed in himself, and he sat down again on the big stone and reflected. Suddenly he jumped up.

"Compassion! Compassion for the higher men!" he cried out, and his face changed to bronze. "Well now! That—has had its time! My suffering and my compassion [Mein Leid und mein Mitleiden] —what does it matter? Am I striving after happiness? I 
am striving after creation [Werk]! Well now! The lion came, my children are near, Zarathustra has ripened, my hour has come: This is my morning, $m y$ day is breaking: rise now, rise, thou great noon!"

Thus spoke Zarathustra, and he left his cave, glowing and strong as a morning sun that comes out of dark mountains. (Z IV “The Sign,” p. 439).

What, exactly, constitutes this revitalizing victory? Inspired by the passage in Ecce Homo which insists that Zarathustra must "overcome" compassion in order to carry on the hard work of creation, Martha Nussbaum interprets the "climax" of Zarathustra's "long spiritual development" as coming only when "he finally gets rid of his pity." ${ }^{, 45}$ Stanley Rosen agrees, arguing that in this moment of "purgation" Zarathustra is finally "cured of pity for the higher men." ${ }^{, 46}$ Robert Pippin specifically sees the "sign" of the lion's appearance (symbolic of strength) as persuading Zarathustra that he is at last free of any sympathetic feelings for these specimens of failed greatness. With this sign, Zarathustra makes a "mysterious, sudden decision that he no longer pities them.",47

This conventional interpretation of the close of Nietzsche's epic, however, is surely incorrect. A close examination of the passage in question reveals that Zarathustra never "overcomes" his compassion in the sense of ridding himself of it once and for all. There is no indication that our hero will fail to experience compassion upon further encounters with suffering, or even that he has ceased to feel compassion for the higher men. Achieving "mastery" over a virtue or sentiment, remember, necessarily implies retaining it in one's psyche, not abandoning it. Rather than ridding himself of all sympathetic sentiments once and for all, Zarathustra affirms his feelings for the higher men as having had their "time" as an essential component of his destiny. Compassion may cause him real misery, but, when properly 
harnessed, it helps rather than hinders Zarathustra's creativity. Indeed, as tightly bound as sympathetic feelings are with the possession of knowledge and the faculty of imagination, they are necessarily present in any creative psyche. Remembering, then, that the telos of human striving is not happiness but creation (more specifically value-creation), the experience of compassion is nothing to be regretted.

While Rosen acknowledges that "the pitiful must be accepted as a natural part of human existence," he nonetheless interprets Nietzsche to maintain that "it must also be destroyed in order for the creation of higher values that will themselves exclude or minimize pity by the imposition of a natural hardness that... is for Nietzsche the indispensable complement to the birth of a race of warrior-artists. ${ }^{, 48}$ Yet value-creation does not require the "destruction" of compassion; it requires affirmation of the imaginative strength which allows the wise to share suffering with the objects of their all-encompassing knowledge. A mere brute warrior may not need to experience compassion, but a warrior-artist and value-creator surely must, albeit without allowing this suffering to interfere with his work. Though the weak may be unable to withstand even the slightest pain, the strong and creative not only withstand their suffering and their sympathetic suffering - they positively embrace them. Such suffering is of no "matter" to them, for it is no hindrance in their creative task, only a hindrance to the pursuit of happiness undertaken by the "last man" and other such degenerates (See Z I Prologue 5, p. 129). Compassion, Zarathustra concludes, is an unbearable burden only for those who mistakenly believe the true goal of human existence to be contentment rather than creation.

Elsewhere, speaking of his philosophical honesty, Nietzsche reasons that, despite this honesty's regrettable aspects, "supposing that this is our virtue from which we cannot get away, we free spirits - well, let us work on it with all our malice and love and not weary of 'perfecting' 
ourselves in our virtue" (JGB VII:227, p. 345$).{ }^{49}$ Zarathustra treats compassion similarly, realizing that sympathetic suffering is inseparable from his imaginative creativity, and then returning to his destined task with the glow of a healthy soul ready to use all his facultiesincluding compassionate imagination —in pursuit of his chosen task..$^{50}$ This, remember, is how value-creation first appears, as a great self-affirmation on the part of the naturally noble (See GM I:2, p. 462). Such a value-creator seizes the right to call even his propensities for sufferingincluding a propensity for the sympathetic suffering of Mitleid — by the name of virtue. The virtue so chosen will inevitably shine forth as a sign of his strength, and be put to service in the advancement of life.

\section{Nietzsche's Warning}

Though my interpretation of Nietzsche's position on compassion may be unconventional, the conviction that Nietzsche's position remains relevant is not. Many, such as Nussbaum, have defended compassion against what they see as Nietzsche's unrelenting critique; by refuting him, they hope to better understand our reasons for embracing the sentiment today. ${ }^{51}$ Yet the temptation here is to misinterpret Nietzsche so as to render him easier dialectical prey. Nussbaum's critic Weber, though sharing Nussbaum's misreading of Nietzsche as a straightforward opponent of compassion, moves closer to a true understanding of Nietzsche's position by considering that it might be basically correct. "In a world in which so many suffer while a small minority flourishes," Weber acknowledges, "it is easy to invest all one's energy... into the plight of those who suffer, and to lose sight of-perhaps even to develop a certain contempt for-the more privileged and... the realization of the highest human excellences." 52 Although Weber doubts that these concerns will turn many today into opponents of compassion, 
he remains convinced that Nietzsche's description of "the pitfalls and pathologies" of the sympathetic sentiments serves as a "good warning" for all those who might overvalue these emotions. ${ }^{53}$

Weber, however, only captures half of Nietzsche's warning. There is a second way in which the painful experience of compassion can threaten human excellence. Not only do we risk developing contempt for all but the suffering masses, but we also risk developing contempt for the compassion that forces us to suffer with them. The terrible experience of shared suffering might lead some of the would-be great on a futile quest to abolish human misery. Others, however, are likely to conclude that their sympathetic pain could be most efficiently relieved by extirpating the faculties responsible for it. When we do not hate the suffering of others, but only our own sharing of this suffering, we seek only to banish compassion from our own breasts. Doing so, however, requires us to shield ourselves from the troubling awareness of our fellows' plight, to sever the imaginative and emotional bonds which connect us to others. It requires that we turn against our own strength of intelligence and imagination, that we sacrifice knowledge for ignorance by denying our insights into the human condition. Some of us might succeed in turning ourselves into such isolated, unthinking beings, but such individuals are not destined for creative achievement.

By contrast, the natural philosopher, poet or psychologist — the born and inevitable unriddler of human souls - could no more destroy his own sense of compassion than he could abolish the human suffering which compassion compels him to share. A futile quest to extirpate his sympathetic sentiments would only turn such an individual against the world, against life, and against himself; in the end, it might even destroy him. Zarathustra does not pass the greatest test of his strength by purging compassion from his psyche. To the contrary, he affirms his painful 
experience of the emotion as creativity-enhancing and life-promoting. In doing so, Nietzsche's protagonist warns against those who unduly oppose compassion as well as those who unduly celebrate it. Both sides treat pain as something to be soothed away rather than harnessed for creative purposes; they differ only in whether the pain to be alleviated is our own or that of others. From the ethically authoritative perspective of life, both can be seen as opponents of human flourishing.

Zarathustra's success in embracing compassion, however, does not necessarily reflect such success on the part of his creator. Throughout his interpretation of Thus Spoke Zarathustra, Pippin reminds us to keep careful track of an "irony" infusing Zarathustra's teachings, an irony stemming from "a lack of identity between the self-understanding of a character and that of the author and, by virtue of that difference, a potential negative qualification of what is said or done by that character. ${ }^{, 54}$ While Zarathustra may have resolved the question of compassion by affirming his sympathetic sentiments, "there is no reason to think that the ironic distance between Zarathustra and Nietzsche has been overcome." ${ }^{\text {,5 }}$

Yet the distinction between an author and his character need not privilege the real over the fictional person; the "potential negative qualification" might be better applied to what is said or done by the writer, not by his creation. Nietzsche may have crafted a great test and created a character capable of passing this test, without having sufficient strength to pass it himself. ${ }^{56}$ Indeed, Nietzsche repeatedly complains in his correspondence that "Schopenhauer's 'compassion' has always been the major source of problems in my life." ${ }^{57}$ It has even been suggested that his hostility toward compassion may have played a role in Nietzsche's ultimate destruction; the famous breakdown of 1889 has been interpreted by several of Nietzsche's biographers as being brought on by an unbearable compassion with the lowliest of sufferers, a 
horse being beaten by its driver. ${ }^{58}$ In this way, Nietzsche might not only pronounce a warning about the life-denying dangers of excessive opposition to compassion; he might also serve as such a warning himself.

Nietzsche was well aware that his general approach to ethics, together with his insightful evaluation of Mitleid, demanded that the noble soul embrace its own sympathetic sentiments. Yet Nietzsche was also aware that every great philosophy is "the personal confession of its author and a kind of involuntary and unconscious memoir" (JGB I:6, p. 203). Perhaps the greatest sin that Nietzsche confesses in his philosophy is a failure to make peace with a world filled with misery in which knowledge of the human condition is inseparable from compassionate suffering. Since his fierce denunciations of the undue celebration of compassion so overwhelmingly outnumber his denunciations of its undue rejection, Nietzsche appears to be a much more straightforward critic of shared suffering than his immoralist ethics warrants. ${ }^{59}$

Although Nietzsche may have lacked the fortitude to endure the pain of his tremendous compassion for others, this very compassion animated his greatest creative achievements, most notably the fourth part of Thus Spoke Zarathustra. The moving portraits of the higher men—not to mention the compelling account of Zarathustra's long struggle to endure and ultimately embrace his sympathetic feelings for them—would have been impossible had the author lacked deep compassion for each and every one of his characters, as well as for their real-world models. Yet even as Thus Spoke Zarathustra remains an eloquent example of the creative achievements possible only through compassion, the anguish which allowed for its composition may have been too much for its author to bear. 


\section{$\underline{\text { Notes }}$}

I would like to thank Coral Celeste, George Kateb, Stanley Corngold, Stephen Macedo, Jeffrey Stout, Tracy Strong, Tamsin Shaw, Patrick Deneen, Casiano Hacker-Cordón, Amy Shuster, John Holzwarth, Alex Zakaras, Catherine Zuckert and the anonymous reviewers at The Review of Politics for their helpful comments and suggestions. Earlier versions of this paper were presented at the Princeton University Graduate Research Seminar in Political Theory and at the 2004 meeting of the Western Political Science Association.

${ }^{1}$ The central place of compassion in our popular political discourse is well known; our most recent Democratic president famously trumpeted his ability to feel others' pain, and his Republican replacement still assures us that his conservatism remains compassionate. This popular infatuation with compassion has also spread into academic moral and political theory. For an important example of a contemporary theorist of compassion-one who provides extensive references to other such theorists - see Martha Nussbaum, "Compassion: The Most Basic Social Emotion," Social Philosophy and Policy 13 (1996): 27-58, and the corresponding chapters in Nussbaum, Upheavals of Thought: The Intelligence of Emotions (New York, Cambridge University Press, 2001), pp. 297-456.

${ }^{2}$ Whenever possible, all quotations from Nietzsche in English are from the translations by Walter Kaufmann, R. J. Hollingdale, or the two in collaboration. When necessary for the point at hand, however, I have either modified Kaufmann and Hollingdale's translations (most notably by always changing the translation of Mitleid from "pity" to "compassion") or quoted directly from the German original in the Colli/Montinari edition, available online through Intelex Past Masters at http://www.library.nlx.com/. I also consulted the 1930 edition of Nietzsche's Werke published 
by Alfred Kröner, Leipzig, as the collection of Nietzsche's notes published under the title Der Wille zur Macht is not included in the Colli/Montinari edition in the edited form translated by Kaufmann. Nietzsche's works will be cited parenthetically, along with section names or numbers and page numbers in their respective translations, according to the following standard system of abbreviations:

GT: Geburt der Tragödie. (1872/1886) Translated by Kaufmann as The Birth of Tragedy in The Basic Writings of Nietzsche (New York: The Modern Library, 1966/1992), pp. 1-145.

MAM: Menschliches, Allzumenschliches. (1878/1886). Translated by Hollingdale as Human, All Too Human (New York: Cambridge University Press, 1986).

MR: Morgenröte. (1881). Translated by Hollingdale as Daybreak (New York: Cambridge University Press, 1982).

FW: Die Fröhliche Wissenschaft (1882/1887). Translated by Kaufmann as The Gay Science (New York: Vintage Books, 1974).

Z: Also Sprach Zarathustra. (1883-1885) Translated by Kaufmann as Thus Spoke Zarathustra in The Portable Nietzsche (New York: Penguin Books, 1954/1982), pp. 103-440.

JGB: Jenseits von Gut und Böse (1886) Translated by Kaufmann as Beyond Good and Evil in Basic Writings, pp. 179-436.

GM: Zur Genealogie der Moral (1887) Translated by Kaufmann as On the Genealogy of Morals in Basic Writings, pp. 437-600.

EH: Ecce Homo (Written 1888, Published 1908). Translated by Kaufmann in Basic Writings, pp. $655-800$.

GD: Götzendämmerung (1889) Translated by Kaufmann as Twilight of the Idols in The Portable Nietzsche, pp. 463-564. 
AC: Der Antichrist (Written 1888, Published 1895) Translated by Kaufmann in The Portable Nietzsche, pp. 565-656.

WM: Der Wille Zur Macht (Collected from Nietzsche's Notebooks of 1863-1888, 1906)

Translated by Kaufmann and Hollingdale as The Will to Power (New York: Vintage Books, 1968).

${ }^{3}$ For more on Nietzsche as siding with Hume in the battle for domination between reason and passion, see Leslie Paul Thiele, Friedrich Nietzsche and the Politics of the Soul: A Study of Heroic Individualism (Princeton, NJ: Princeton University Press, 1990), p. 56.

${ }^{4}$ Ruth Abbey similarly observes that Nietzsche's critique of compassion can "be read as selfcritique in two ways: he is not just trying to deny this powerful strain in his own personality, but is also trying to purge himself of his past affinity with Schopenhauer" (Ruth Abbey, Nietzsche's Middle Period [New York: Oxford University Press, 2000], p. 62). For the best general theory of oedipal struggle with one's intellectual and artistic forbearers, see Harold Bloom, The Anxiety of Influence (New York: Oxford University Press, 1973). As Abbey notes, however, Bloom is incorrect to view Nietzsche as an author who "did not feel the chill of being darkened by a precursor's shadow" (Bloom, p. 50; Abbey, p. 199).

${ }^{5}$ Given that compassion has only recently emerged as a central theme in our political rhetoric, the political-theoretical literature critiquing the sympathetic sentiments remains relatively small. Interestingly, given his reputation as a defender of pitié, Rousseau has been the touchstone for many of today's academic critics of compassion. See, for example, Clifford Orwin, "Rousseau and the Discovery of Political Compassion," in Clifford Orwin and Nathan Tarcov, eds., The Legacy of Rousseau (Chicago: The University of Chicago Press, 1997), pp. 296-320 and Richard 
Boyd, "Pity's Pathologies Portrayed: Rousseau and the Limits of Democratic Compassion," Political Theory 32:4 (August 2004): 519-546.

${ }^{6}$ Henry Staten, Nietzsche's Voice (Ithaca, NY: Cornell University Press, 1990), p. 1.

${ }^{7}$ For a brief but wide-ranging review of the recent literature on Nietzsche's critique of compassion, see Abbey, p. 175. For one of the most extended discussions on the topic, which will serve as an important foil for my own views throughout this essay, see Martha $\mathrm{C}$. Nussbaum, "Pity and Mercy: Nietzsche's Stoicism" in Richard Schacht, ed. Nietzsche, Genealogy, Morality: Essays on Nietzsche's On the Genealogy of Morals (Berkeley, CA: University of California Press, 1994): 139-147. Much of the material in this essay is re-used in Chapter 7 of Nussbaum's Upheavals of Thought.

${ }^{8}$ Thiele (p. 152) is one exception to this general rule, but discusses Nietzsche's qualified endorsement of compassion in only a few all-too-brief paragraphs; Thiele's important, if underdeveloped, insights will be cited in their appropriate context. Abbey's chapter on the subtle evaluation of compassion in Nietzsche's "middle period" (pp. 55-71) is another important exception to this rule. Yet while Abbey grants that in Nietzsche's later works "some echoes of the more sensitive and nuanced portrayal of pity offered in the middle period" may remain, she argues that in these "shriller and more simplistic" texts "pity becomes a byword for many of the perils that Nietzsche identifies... rather than a mystery of the psyche to be unraveled with care and delicacy." Abbey concludes that, as on a number of other subjects, the views on compassion that Nietzsche abandoned by 1883 are superior to those advanced in his later works (Abbey pp. 70-71, p. 156). While I agree with much of Abbey's interpretation of Nietzsche's writings from before 1883, I disagree with most of her characterizations of Nietzsche's writings from after that year. The present essay will analyze Nietzsche's mature position on compassion by drawing on 
writings from throughout the 1880 's - including both works of the "middle period" at the beginning of that decade and the final period of productivity at the end of it, but focusing primarily on the three interrelated works of 1883-7 which are Nietzsche's greatest legacy: Thus Spoke Zarathustra, Beyond Good and Evil and On the Genealogy of Morals. This essay argues that the subtlety which Abbey describes as characteristic only of Nietzsche's "middle period" position on compassion is in fact Nietzsche's characteristic of his mature position on the subject simpliciter. That said, Abbey's important insights, like Thiele's, will be cited as appropriate. ${ }^{9}$ The first, classic statement of this view is Gilles Deleuze, Nietzsche and Philosophy (1962). Translated by Hugh Tomlinson (New York: Columbia University Press, 1983), especially pp. 13. It was made famous by Foucault's 1971 essay, "Nietzsche, Genealogy and History." Reprinted widely in many languages, this piece may now be found most readily in the 1977 English translation by Daniel F. Bouchard and Sherry Simon in The Foucault Reader. Edited by Paul Rabinow (New York: Pantheon Books, 1984), pp. 76-100.

${ }^{10}$ Jacqueline Stevens, for example, has convincingly argued that Darwinian "genealogists of morals" such as Nietzsche's estranged friend Paul Rée are the "worthless" opponents against which Nietzsche sets his own views in his self-described "polemic" On the Genealogy of Morals. See Jacqueline Stevens, “On the Morals of Genealogy,” Political Theory 31:4 (August 2003): 558-588. (Nietzsche calls genealogists of morals "worthless" at GM II:4 p. 498.) The current secondary literature on Nietzsche's alleged method of "genealogy" is, of course, far too vast to review here in its entirety; an excellent starting point are the essays collected in Schacht, ed., particularly those in Part II, pp. 251-468.

${ }^{11}$ As Nietzsche puts it a little later, "we need a critique of moral values, the value of these values themselves must be called into question — and for that there is needed a knowledge of the 
conditions and circumstances in which they grew, under which they evolved and changed" (GM

Preface 6, p. 456).

${ }^{12}$ This point is discussed at greater length in Raymond Geuss, "Nietzsche and Genealogy," in Morality, Culture and History: Essays on German Philosophy (New York: Cambridge

University Press, 1999): 1-28; see especially pp. 20-21.

${ }^{13}$ Deleuze, for one, argues that Nietzsche's "perspectivism" demonstrates that "knowledge itself is an illusion; knowledge is an error, or worse, a falsification" (Deleuze, p. 90).

${ }^{14}$ Alexander Nehamas, Nietzsche: Life as Literature (Cambridge, MA: Harvard University Press, 1985), p. 105. See also pp. 126-129, 214-217.

${ }^{15}$ See, for example, Ibid., p. 84.

${ }^{16}$ Staten, p. 6. In searching for an answer here, however, Staten readily admits that he is "not primarily interested in debating the cogency of Nietzsche's doctrines" (p. 129) - that is, as I take it, with making philosophical sense of them. For a more philosophical take on these issues, see Raymond Geuss, "Nietzsche and Morality," in Morality, Culture and History (op. cit): 167-198, especially pp. 181-185.

${ }^{17}$ Martin Heidegger, Nietzsche: Volumes I and II. Translated by David Farrell Krell (San Francisco: Harper San Francisco, 1979/1984/1991), I:13, I:1, p. 4.

${ }^{18}$ Heidegger, "The Word of Nietzsche: 'God is Dead'” (1943). Collected in The Question Concerning Technology and Other Essays. Translated by William Lovitt (New York: Harper Torchbooks, 1977), pp. 53-114. See p. 53 and p. 75. Heidegger later explains that "as a mere countermovement" Nietzsche's worldview "necessarily remains, as does everything 'anti,' held fast in the essence of that over against which it moves" (p. 61). 
${ }^{19}$ Peter Berkowitz, Nietzsche: The Ethics of an Immoralist (Cambridge, MA: Harvard University Press, 1995); see pp. 96-99. Stanley Rosen's interpretation of Nietzsche is allied with that of Berkowitz, who clearly concurs with Rosen's claim that commentators such as Delueze and Foucault, with their "emphasis on difference to the neglect of rank-ordering, and on the multiplicity of perspectives to the neglect of Nietzsche's classification of these perspectives into a finite number of [ranked] types" have "led to a vulgarization of his [Nietzsche's] teaching that is unfortunately typical of our time" (Stanley Rosen, The Mask of Enlightenment: Nietzsche's Zarathustra [New York: Cambridge University Press, 1995], p. 151). It is tempting to treat those who read Nietzsche primarily in terms of "genealogy" and "perspectivism" as "leftist," and those who read Nietzsche along more traditional, Platonic or Aristotelian lines as "conservative," but I have deliberately avoided such politically-loaded labels.

${ }^{20}$ Nehamas, p. 68.

${ }^{21}$ See John Rawls, A Theory of Justice. Revised Edition (Cambridge, MA: The Belknap Press of Harvard University Press, 1971/1999), p. 22.

${ }^{22}$ A convincing argument that Nietzsche is indeed a virtue ethicist in this sense can be found in Thomas H. Brobjer, "Nietzsche's Affirmative Morality: An Ethics of Virtue," Journal of Nietzsche Studies 26 (2003): 64-78.

${ }^{23}$ Consider the following relativist advice from Zarathustra:

If you have a virtue and she is your virtue, then you have her in common with nobody. To be sure, you want to call her by name and pet her... And behold, now you have her name in common with the people and have become one of the people and herd with your virtue... May your virtue be too exalted for the familiarity of names... [Just say of her] 'This is $m y$ good; this I love; it pleases me wholly; thus alone do $I$ want the good. I do not 
want it as divine law; I do not want it as human statute and need... there is little prudence [that is, Aristotelian practical wisdom or phronesis] in it, and least of all the reason of all men. (Z I "Of Enjoying and Suffering the Passions," p. 148).

${ }^{24}$ Staten, p. 169.

${ }^{25}$ See GM I:2, p. 462. Even the weaknesses of the otherwise strong may thus be called by the name of virtue. "One thing is needful," Nietzsche writes. "To 'give style' to one's character-a great and rare art! It is practiced by those who survey all the strengths and weaknesses of their nature and then fit them into an artistic plan until every one of them appears as art and reason and even weaknesses delight the eye" (FW 4:290, p. 232).

${ }^{26}$ Nietzsche here goes on to observe that, even if we can determine what would constitute the health of a single individual, "the great question would still remain whether we can really dispense with illness... and whether... the will to health alone is not a prejudice, cowardice, and perhaps a bit of very subtle barbarism and backwardness" (FW 3:120, p. 177). Nietzsche himself is thus no unthinking celebrant of health and strength, even as he ultimately does embrace the perspective of life as ethically authoritative.

${ }^{27}$ For asceticism, see GM III. For skepticism, see, for example, JGB VI:208. It is hardly worth listing Nietzsche's countless discussions of pessimism, but GT 7 is as good a place to begin as any. There are also many other examples of such doubling throughout Nietzsche's corpus; to cite just one more example, see Zarathustra's description of chastity as a virtue in some and a vice in others in Z I: “On Chastity,” pp. 166-167.

${ }^{28}$ Abbey argues that for the Nietzsche of the middle period "emotions and drives are not ruled out a priori... As a consequence, Nietzsche does not rule out a drive like pity; everything depends upon who is experiencing it, why and how, with whom and to what ends" (Abbey, pp. 
69-7070). As was mentioned earlier, what Abbey holds true primarily of the middle-period Nietzsche, this essay maintains is true of Nietzsche throughout his mature philosophical career, most notably in the masterworks of the mid-1880's.

${ }^{29}$ According to the Oxford English Dictionary, "pity" from the Latin, "pietas," which originally meant only "piety" and came to take on the secondary meaning of "pity" in the late medieval period. See http://dictionary.oed.com/.

${ }^{30}$ This should lead us to be deeply suspicious of English-language commentators who insist that, while Nietzsche adamantly rejects "pity," he is not necessarily opposed to "compassion;" Randall Havas, for example, occasionally makes claims along these lines. See Randall Havas, Nietzsche's Genealogy: Nihilism and the Will to Knowledge (Ithaca, NY: Cornell University Press, 1995), p. 215, p. 222. I would like to thank Molly Loberg for reconfirming my less-thanperfect understanding of the subtle connotations of particular German terms.

${ }^{31}$ Although Mitleid is almost always rendered as "pity" in English translations of Nietzsche, in the standard English translations Schopenhauer of by E. F. J. Payne the same term is almost always translated as "compassion." (See, e.g., Schopenhauer, On the Basis of Morality [1839]. Translated by E. F. J. Payne [Providence, RI: Berghan Books, 1995].) It makes an important difference whether we see the dispute between Nietzsche and Schopenhauer over Mitleids-Moral as a debate over (as most translators of Nietzsche would have it) "the morality of pity" or (as Schopenhauer's translator Payne would have it) "the morality of compassion."

${ }^{32}$ David Cartwright observes that Nietzsche's conception of compassion as a contagion has its inspiration in Kant, as do several of his more specific arguments regarding the sentiment discussed in this section; see David E. Cartwright, "Kant, Schopenhauer and Nietzsche on the Morality of Pity," Journal of the History of Ideas. 45:1 (January 1984): 83-98. 
${ }^{33}$ Havas correctly rejects any reading of Nietzsche on compassion which interprets his position "as though pity were, in his view, merely one vice among many" (Havas, p. 211). Havas chides Richard Schacht for putting forward such an interpretation, though this seems to be an unduly harsh reading of Schacht; see Richard Schacht, Nietzsche (Boston: Routledge and Kegan Paul, 1983), especially pp. 359-362, p. 461.

${ }^{34}$ Martha Nussbaum, highlighting her observation of Nietzsche's undeniable debt to the ancient Stoics on this point, places this line of thought at the heart of Nietzsche's opposition to compassion. See Nussbaum, Upheavals of Thought, Ch. 7, esp. pp. 384-385, as well as the essay in Schacht, ed. Stanley Rosen concurs, arguing that, for Nietzsche, pity is "the true form of heartlessness" because it "tolerates sickness and cowardice" (Rosen, p. 105). This argument is also discussed in Havas, p. 214. Nussbaum's primary error in her interpretation of Nietzsche, one not shared by Rosen, is that she puts far too great an emphasis on this Stoic line of argument alone. M. Weber has convincingly argued that "insofar as Nussbaum tries to bring Nietzsche into the Stoic fold, she misses or misconstrues much of what he has to say." While it is true that "there are surely traces of Stoicism to be found in Nietzsche... this should not lead us to interpret all he says in Stoic terms." See M. Weber, "Compassion and Pity: An Evaluation of Nussbaum's Analysis and Defense," Ethical Theory and Moral Practice 7 (2004): 487-511, p. 507.

${ }^{35}$ This eugenic argument is emphasized in Tracy Strong's brief discussion of Nietzsche on "pity" in Tracy B. Strong, Friedrich Nietzsche and the Politics of Transfiguration. Expanded Edition (Urbana, IL: University of Illinois Press, 1975/2000). "Pity," Strong writes, "is thus a form of the will to power engendering, and characterizing, nihilism: it preserves that which is characteristic of nihilism" (p. 254). 
${ }^{36}$ This is Nietzsche's own hermeneutic principle: “'Je ne méprise presque rien,' ['I despise almost nothing'] he [the objective, scientific spirit] says with Leibniz," Nietzsche writes. "One should not overlook and underestimate that presque" (JGB VI:207, p. 318).

${ }^{37}$ The quoted passages show the error of Lesley Chamberlain's claim, "There is no pity in the world of Dionysus," at least if "pity" is presented (as Chamberlain herself presents it) as a translation of Nietzsche's Mitleid or Mitledigkeit. See Lesley Chamberlain, Nietzsche in Turin: An Intimate Biography (New York: Picador USA, 1996), pp. 103-104. Despite this error, Chamberlain does not read Nietzsche as a straightforward critic of compassion; see, e.g., p. 179. ${ }^{38}$ This idea that "pity" leads to "epistemological confusion"- and in its presumptive claim to know another's suffering actually acts against real knowledge of the suffering other-is at the heart of Randall Havas' interpretation of Nietzsche on the subject. See Havas, esp. pp. 220-223. ${ }^{39}$ See, for example, Bernard Williams, Ethics and the Limits of Philosophy (Cambridge, MA: Harvard University Press, 1985), p. 14.

${ }^{40}$ Jean-Jacques Rousseau, Emile or On Education (1762). Introduction, Translation and Notes by Allan Bloom (New York: Basic Books, 1979), p. 222.

${ }^{41}$ Staten, pp. 154-155.

${ }^{42}$ Strangely, Havas reads this passage as further evidence that, for Nietzsche, "pity" is opposed to real knowledge; see Havas, p. 233. Havas associates "pity" with the avoidance of intercourse with one's fellows, while Nietzsche here clearly does the opposite. This passage explicitly describes sympathy (Mitgefühl) as the price of human interaction and real knowledge of others. While Nietzsche here avoids his usual terminology of Mitleid, the feelings shared in this experience of Mitgefühl are obviously painful ones, hence qualifying the Mitgefühl as Mitleid. 
${ }^{43}$ As one must so often do when citing Nietzsche, it is important to note that the author of the present essay does not share Nietzsche's misogyny, so painfully evident in this passage. At the same time, we must not make too much for interpretive purposes of the misogynistic language here, which comes quite naturally to Nietzsche. Surely it does not do much to explain Nietzsche's subtle position on compassion to simply conclude, with Chamberlain, that Nietzsche "allowed himself to accept pity in the male" (Chamberlain, p. 117).

${ }^{44}$ This reading of the fourth part of Thus Spoke Zarathustra as built around the theme of compassion is discussed at length in Rosen's commentary on the work (See Rosen, pp. 207-244). While I agree with much of Rosen's commentary, it will soon become clear that I depart from him decisively on the interpretation of the book's concluding episode, and hence on Nietzsche's real position on compassion.

${ }^{45}$ Nussbaum in Schacht, ed., p. 139, 152.

${ }^{46}$ Rosen, p. 228, 244.

${ }^{47}$ Robert Pippin, "Irony and Affirmation in Nietzsche's Thus Spoke Zarathustra," in Michael Allen Gillespie and Tracy B. Strong, eds., Nietzsche's New Seas: Explorations in Philosophy, Aesthetics and Politics (Chicago: The University of Chicago Press, 1988): 45-74, p. 64.

${ }^{48}$ Rosen, p. 231.

${ }^{49}$ This is intimately tied to the idea of "“'giving style' to one's character" cited previously (FW 4:290, p. 232).

${ }^{50}$ Leslie Paul Thiele, one of the few commentators to notice that Nietzsche "did not desire the extirpation of fellow-feeling, but the vanquishing of its decadent form" describes the form of compassion which Nietzsche endorses as "a form of compassion which uses suffering as a means to the elevation of man... Love must be strong enough to carry out its harsh task in the 
transformation of suffering, for only then will its compassion not be an aid and abetment to cowardice and stagnation" (Thiele, p. 152). Unfortunately, Thiele does not develop his insights on the matter much beyond the passages quoted.

${ }^{51}$ More specifically, Nussbaum treats Nietzsche as part of a larger tradition of anticompassionate thinkers who "defend a substantive and highly controversial ethical position" which very few today would "actually be prepared to endorse" but which "can clear the ground for a more adequate contemporary approach" to compassion in politics (Upheavals of Thought, p. 356).

${ }^{52}$ Weber, p. 510.

${ }^{53}$ Ibid.

${ }^{54}$ Pippin, p. 65.

${ }^{55}$ Ibid., pp. 58-59.

${ }^{56}$ Rosen concurs with this view, writing that "Zarathustra is the highest and purest aspect of Nietzsche's spirit; he stands for what Nietzsche would wish himself to be but cannot become." Given his conventional interpretation of Zarathustra's ultimate triumph, however, Rosen goes on to claim (incorrectly, in my view) that Zarathustra is a better Nietzschean than Nietzsche himself, not because Zarathustra is able to affirm his sympathetic sentiments while Nietzsche is not, but because "Nietzsche is still bound to the domain and decadence and death by the feeling of pity" (Rosen, p. 218). Leslie Paul Thiele's view on the matter is, despite his real insight into Nietzsche's qualified endorsement of compassion, surprisingly similar to Rosen's. "The final victory over pity of the protagonist of Thus Spoke Zarathustra," Thiele writes, "would appear not to have been granted to its author" (Thiele, p. 153). 
${ }^{57}$ Letter of July 1883 to Malwida von Meysenberg, Quoted and Translated in Rüdiger Safranski, Nietzsche: A Philosophical Biography. Translated by Shelley Frisch. (New York: W. W. Norton, 2000/2002), p. 167. A particularly pathetic letter from the winter of 1882, cited by Nietzsce's English-language biographer Curtis Cate, finds the philosopher complaining to Lou Salomé and Paul Rée of "a dreadful compassion... [H]ow can I endure it any longer? Is not compassion a feeling out of hell? What should I do? Every morning I despair of lasting out the day... Whence come these fierce emotions... This evening I will take so much opium that I will lose my reason; where is there a h[uman] b[eing] one could still revere?" (Cited and translated in Curtis Cate, Friedrich Nietzsche [London: Hutchinson, 2002], p. 389.) See also the larger discussion by Safranski of the place of pity in Nietzsche's own psyche (Safranski, pp. 166-168) and the similar discussions by Lesley Chamberlain (Chamberlain, pp. 104-105, 156, 172).

${ }^{58}$ See, e.g., Safranski, p. 316; Chamberlain, pp. 208-210; Cate, p. 550. As Curtis Cate observes, the incident of Nietzsche throwing his arms around a beaten horse at the moment of his collapse in Turin was first reported in an Italian newspaper thirteen years after the incident in question, but it is now included in most biographies of the philosopher (Cate, p. 550). For a thorough review of the various available accounts of the incident see Anacleto Verrechia, La catastrophe di Nietzsche a Torino (Turin: Einaudi, 1978), especially pp. 207-210. As the anonymous reviewers of this essay correctly pointed out, it would be overly reductive to attribute Nietzsche's collapse to unbearable compassion alone; more mundane medical factors obviously played an important role. Leslie Paul Thiele concludes that while we must resist the temptation "to suggest that pity (for an animal) proved to be Nietzsche's ultimate undoing" it is still the case that the "symbolism" of this incident "is too striking to be discounted" (Thiele, p. 153).

${ }^{59}$ Ruth Abbey has also made this point; see Abbey, pp. 61-63. 